\title{
Determination of The Writing Errors of Bilingual Turkish Students in France (Example of Lyon)
}

\author{
Vedat Halitoğlu * \\ Alanya Alaaddin Keykubat University, Department of Turkish Education, Turkey \\ ORCID: 0000- 0001-9557-7782
}

Article history

Received:

07.01.2021

Received in revised form: 29.04.2020

Accepted:

05.05.2021

Key words:

Bilingualism;

Turkish language teaching; France
This study tried to determine the errors in writing samples to clarify the proficiency and deficiency of writing in the mother tongue of Turkish children who live in France. Participants in the study included 25 students who studied Turkish and Turkish culture at the level of primary and secondary public schools in Lyon, France. In the research, document analysis method was used within the framework of the qualitative research model. Twenty-five writing papers collected after a writing task assigned by Turkish and Turkish culture teachers during the class including 4,695 words, constitute the data set of the research. Writing samples obtained from students were accepted as documents and subjected to content analysis. Content analysis was done through Nvivo 12 qualitative data analysis program, which is frequently used in qualitative research. Within the scope of the research, a total of 1669 error codes were obtained in four categories from the documents. It was seen that the highest number of errors occurred in the category of writing errors with the error code 656, followed by spelling errors with the error code 622 , inter-language transfer errors with the error code 248 , and punctuation errors with the error code 143. The result is that students in France should go through a more qualified learning process in their native language writing skills.

\section{Introduction}

\section{Teaching Mother Tongue in Europe}

People have been displaced for many reasons throughout the history. According to the International Organization for Migration's report, the migrants were identified as refugees, victims of their cultural roots, or internally displaced persons (IOM, 2004), and as being interchangeable with economic reasons. After the Second World War, there was a reconstruction process of France, and immigrants from many states emigrated to France as workers on economic grounds. After the signing of the first international migration treaty between Turkey and France in 1965, Turks started their departure for France (Yardim, 2017). From then on, Turks who had briefly stayed and returned after earning money eventually settled there (Kaya, 2008; Kocak \& Gunduz 2016; Yavuz, 2013). Over time, there has been a

\footnotetext{
* Correspondency: vedat.halitoglu@alanya.edu.tr
} 
tendency for the second- and third-generation children to forget their mother tongue, and they have been oriented towards a second language since there have been less number of environments to use their mother tongue (Ozdemir, 2016; Pilanci, 2009). A number of transition models and instructional programs have been introduced in Europe in the interest of immigrant children, to teach the language of the host country and to ensure the language adjustment of immigrant children. These can generally be expressed as follows (Baldik, 2018):

- Support measures for compensating the language needs of immigrant students whose mother tongue was not their language of education: In general, it corresponds to the lessons of "linguistic diving" in which, during the regular school hours, students are directly exposed to the target language and took intensive courses (special language support) individually or in small groups. "Bilingual" classes are taught partially in the language of education and partially in the mother tongue of the students.

- Support measures aimed at addressing the learning needs of immigrant students in specific areas of the curriculum in their learning status. Under these circumstances, the content and teaching methods of the primary teaching program can be changed on a specific basis. Curriculum support can be organized, and immigrant students are sometimes not evaluated like other students.

- Classes can be reduced for a more favourable student/teacher ratio.

Based on these models, it is intended to increase compliance and teaching of the second language only. But with political concerns regarding the mother tongue of immigrant children, no steps have been taken in this sense, or they have been prevented. However, this situation differs according to the countries. While some countries approach to this subject positively and allow for the teaching of the mother tongue, some countries prohibit mother tongue teaching in schools. For example, in Germany, mother-language teaching varies somewhat by state, but it is led by teachers who are assigned under the responsibility of the German Authority of Education or bound to the agreements with the countries the immigrants come from (Teachers of Turkish and Turkish Culture) (Yildiz, 2012). Contrary to these practices, Denmark, Norway and the Netherlands have completely eliminated their mother tongue courses from primary schools since 2004 (Yagmur, 2006). In France, Turkish mother tongue teaching activities can be carried out in two ways in schools. Lessons can be held under the name of ELCO (Learning the language of origin and culture) or foreign language teaching (Akinci, 2007). Turkish and Turkish culture teachers are appointed by the Turkish Republic each year to give such lectures in France.

\section{Writing Learning Area}

Turkish language courses are taught within the areas of reading, writing, listening and speaking. Writing has an important place in these areas. Writing is the activity of organizing thoughts on paper and presenting them to the reader in paragraphs and sentences (Meyer, 2006; Nunan, 2003). It can be said that writing requires a more systematic process of knowledge acquisition and includes a set of rules in itself compared to other language learning areas. It also requires mental efforts due to its communicative and productive nature, so it entails a much more difficult and complex development than other learning areas (Akkaya \& Doyumğaç, 2020; Evans, 2001; Harris \& Cunningham, 1994; Zoubi, 2018). Therefore, writing contains top-level cognitive steps, undertakes a manufacturing and communicative function, and requires a productive and active process like speech (Graham \& Perin, 2007; Lv \& Chen, 2010; Weinstein \& Hume, 1998). 


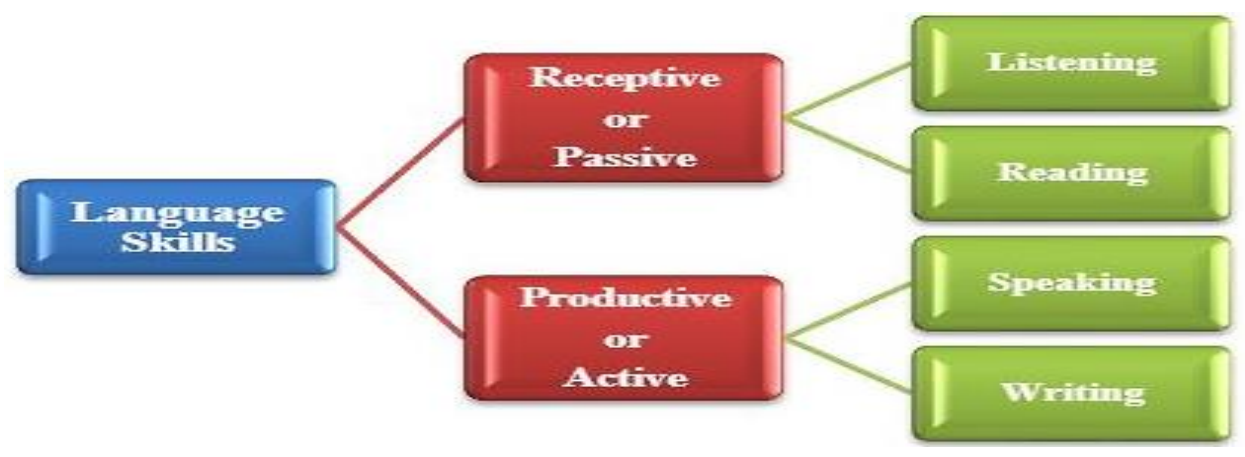

Figure 1. Four Language Learning Skills (Rao, 2019)

Writing includes many special skills such as thinking, organizing, and drafting within itself and a language coordination process that works simultaneously with a working memory (Brown, 2001; Berninger, 2009). Achieving this skill takes an important role in conveying ideas and emotions as desired, and it provides the person with an important learning mechanism (Graham, 2008; Gunes, 2007). For this reason, it is possible to state that the writing learning area has positive effects on learners in many aspects of learning. If a child's writing skills in their mother tongue are strong, it is easier to reach literacy skills in their second language (Reyes, 2006). It is known that the knowledge learned in the mother tongue is transferred to the second language without causing any confusion and has positive contributions to the second language like in early childhood, such as the use of uppercase and lowercase letters, and the pronunciation of letters (Lanauze and Snow, 1989; Gort, 2006; Jared and others, 2011; Dweik and others; Alsamadani, 2010). It is considered that leaving this area incomplete will have negative effects on bilingual students in terms of language and intellectual development. Considering the studies on the language skills of Turkish children living abroad, it is seen that the lack of writing skills has an important place among the language learning areas. It is seen that Turkish children living abroad make mistakes in many subjects such as alphabet, phonetics, spelling and punctuation and have insufficient learning in this area (Sari, 2001, Kalfa ve Mete, 2020; Sen, 2016; Ortakoylu and others, 2020). It is certain that studies in this field will contribute to the writing skills of children living abroad.

\section{Detection of Writing Errors}

Committing errors is an inevitable circumstance that occurs in human learning, including language (James, 1998). A good article has some important features such as draft, capitalization, punctuation, vocabulary, spelling and grammar (El-Aswad, 2002). For these components to come together in a qualified way, it is important to examine students' writing samples, identify and evaluate errors (Ferris, 1999; Gascoigne, 2004; White et al., 1991). Detection of errors will also guide the preparation of an individualized plan and material (Hendrickson, 1978). Hourani (2008) emphasizes that writing errors are important in three ways:

- They tell the teachers how far the students have progressed to the goal and what is left to learn.

- They give researchers the signs of the strategies and procedures that students apply when exploring or learning the language.

- They are indispensable signs for students' mislearning.

In particular, incorrect analysis of bilingual students' writings will guide teachers and 
researchers in the detection and elimination of transfers from the mother tongue (L1) or the second language (L2) (Doff, 1993; Gass \& Selinker, 2001; Nguyen, 2018; Schachter \& Mrianne, 1977; Zafar, 2016), because the moment an individual is trapped in writing in two languages, he makes errors in syntax, grammar, word, and in other elements of the language by transferring several elements of his mother tongue or second language (Wang \& Wen, 2002).

The usage of different methods in many studies on spelling analysis of bilinguals is observed through the relevant literature. In some studies, a structured approach is adopted by addressing the elements such as grammar, spelling, and punctuation (Ahmad et al., 2015; Altiparmak \& Demir, 2020; Ardila et al., 2017; Polad, 2018; Shousha et al., 2020), while a broader scope was created by including the (Cetinkaya, 2015; Yilmaz \& Demir, 2020), cognitive and communicative elements in others. The errors were analyzed by categorizing them separately in terms of the related mother tongue and target language in some studies (Kaweera, 2013; Kosasih, 2019; Sijonu, 2018). As a consequence, an error is perceived as the evidence resulting from the language learning process in which the learners use various strategies in learning a new language as well as test the hypotheses (Rattanadilok Na Phuket \& Othman, 2015). Therefore, it is required to state that instead of disputing a de facto method in writing analysis, a mixed approach has been adopted. In the research, headings are created based on the mistakes that emerged in the writing samples obtained from the participants, rather than acting on the previously determined titles. Throughout the research, the answers to the following questions are sought:

(1) What headings do bilingual children from Lyon, France, who speak Turkish as their first language make spelling mistakes?

(2) What is the frequency and intensity of the spelling errors?

\section{Method} analysis.

This section includes the research model, data collection, participants and data

\section{Research Model}

In the research, document analysis method was used within the framework of the qualitative research model. We can describe qualitative research as research using qualitative information collection methods such as monitoring, interviewing and analysis of documents, tracing perceptions and a qualitative process for presenting events in a realistic and holistic way naturally (Yildirim \& Simsek, 2008). In this context, students' writing papers were considered documents and subjected to a systematic procedure of processing for review and assessment of the writing errors in the papers (Bowen, 2009).

\section{Data Analysis}

Content analysis was carried out/performed/conducted to identify linguistic errors contained in student documents, trying to identify and make sense of the data (Gulbahar \& Alper, 2009). The data were given meanings and visualized using the Nvivo 12 program. Nvivo is an analysis program used in the qualitative analysis process (Halicioglu \& Tasgin, 2015). Within the scope of the research, a total of 1669 error codes were obtained. Coding is about creating a system by labeling parts to facilitate understanding in the data text (Cresswell, 2013; Miles \& Huberman, 2014). The codes obtained at the end of the process 
were given meanings by combining them under categories and categories under themes. At the end of the process, four themes such as writing errors, inter-language transfer, punctuation errors and misspellings were obtained.

\section{Participants}

Participant group of the research consists of primary and secondary school students living in Lyon, France. The participants are comprised of twenty-five people, from four different schools. While determining students, an attempt was made to select the students from different education levels and schools in order to provide the maximum diversity (Patton, 2014). As per the research ethics, the names of the participants were not used. Participating students were named with codes such as S1, S2, S3...S25. The school and education levels of the participants are given in the table below.

Table. 1. Participants' Characteristics

\begin{tabular}{lll}
\hline Participants & Schools & Classes \\
\hline S1-S4 & Ecole Elementaire Clermond & 4,5 \\
S5-S12 & Ecole Elementaire Mulsant & 4,5 \\
S13-S18 & College Jules Ferry & $6,7,8$ \\
S19-S25 & College Jean de la Fontaine & $6,7,8$ \\
\hline
\end{tabular}

\section{Data Collection}

The written documents, which are subject to analysis within the scope of the research, consist of the texts produced by the students as part of a writing task in class held by the Turkish and Turkish culture teacher SH, who works in Lyon. In the course, the teacher asked the students to write an essay containing the memories they listened to from their families. Within the scope of this task, 25 written documents were obtained. When all the documents were examined, it was determined that the articles consisted of a total of 4,695 words.

\section{Findings and interpretation}

As a result of the content analysis, the errors made by the students were gathered in four top categories as seen in the table below.

Table 2. Content Analysis Top Codes

\begin{tabular}{lllll}
\hline Content Analysis Top Codes & Frequency (f) & Percentage (\%) & Rank & $\begin{array}{l}\text { Resource Persons } \\
\text { Number (S) }\end{array}$ \\
\hline Writing Errors & 656 & 39,3 & 1 & 25 \\
$\begin{array}{l}\text { Misspellings } \\
\text { Inter-language (From }\end{array}$ & 622 & 37,26 & 2 & 21 \\
$\begin{array}{l}\text { Turkish) transfers } \\
\text { Punctuation Errors }\end{array}$ & 248 & 14,85 & 3 & 15 \\
Total & 143 & 8,56 & 4 & 17 \\
\hline
\end{tabular}

Errors were mostly in the "writing errors" category with the rate of $(\% 39.3)$ and the code number 656. Secondly, "misspellings" followed them with $(37.26 \%)$ and the code number 622. The "Inter-language transfer" heading comes third with the code 248 code and the rate of $(14.85 \%)$. The punctuation errors category ranked last with 143 errors and the rate of $(8.56 \%)$. Detailed explanations about the resulting subcategories are provided and codes of the main headings are interpreted below. 


\section{Writing Errors}

As a result of the content analysis, it is seen that most of the codes are gathered under the category "Writing Errors" (39.05\%) and a total of 656 codes were formed under this heading.

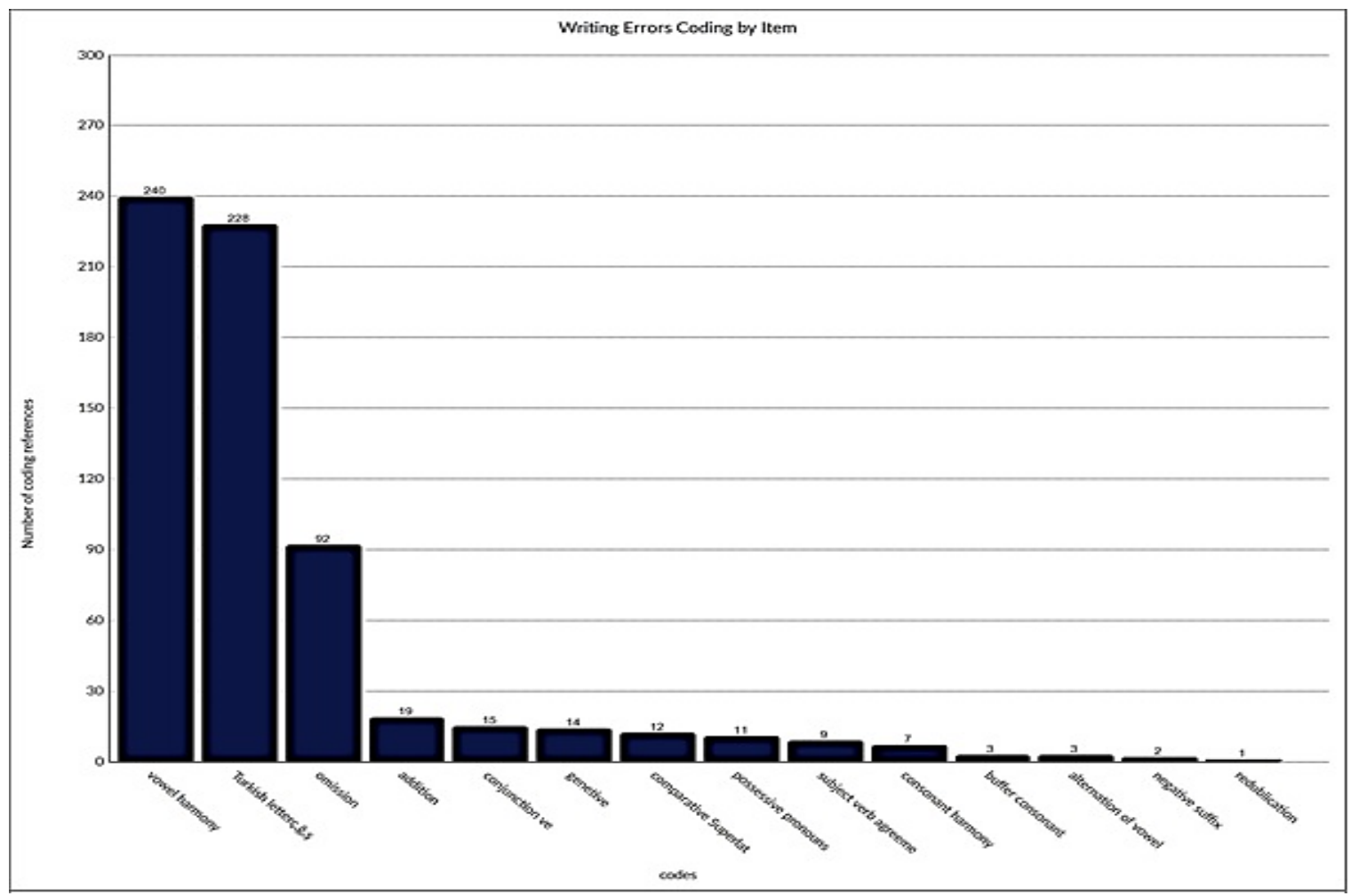

Figure 2. Writing Errors Codes and Numbers

When the main code headings are viewed, vowel harmony, consonants specific to Turkish, omission, addition "ve" conjunction problem, genitive suffix, superiority and supremacy structures, possessive suffix, subject verb mismatch, consonant harmony (assimilation), buffer consonant, alternation of vowel (vowel constriction), negativity suffix and reduplication problems appear to be at the forefront.

It is seen that there are quite a few problems about vowel harmony. $\mathrm{u}-\ddot{\mathrm{u}}, \mathbf{1 - \mathrm { i }}$ and o-ö errors are especially common. It is considered that this results from incomplete learning of vowels specific to Turkish and vowel harmony rules or lack of practice.

$\underline{\text { S14 }}-\S 8$ references coded [2,25\% Coverage]

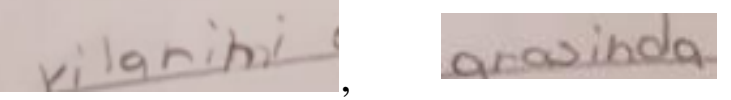

$\underline{\text { S16 }}$ - 44 references coded $[1,01 \%$ Coverage $]$

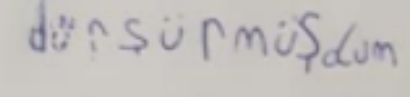

S4 - $\S 3$ references coded $[0,72 \%$ Coverage $]$

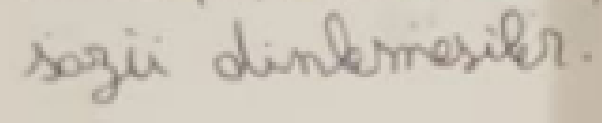


The consonants, ç, $\breve{g}$, ş, which are unique to Turkish, take the second place in the most common errors. Instead of these letters, the letters c, g, s, which are mostly in French, were preferred.

$\underline{\text { S12 }}-\S 3$ references coded $[0,44 \%$ Coverage $]$
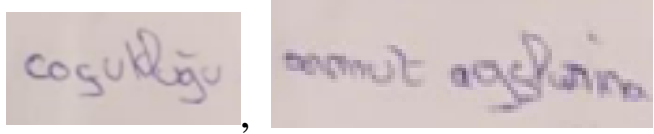

S17 - $\S 10$ references coded $[1,79 \%$ Coverage $]$
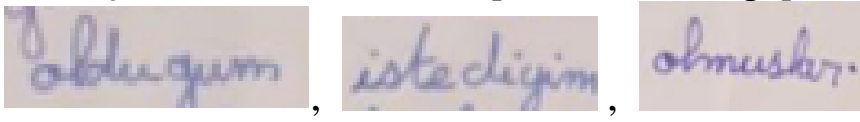

S6 - $\S 2$ references coded $[0,62 \%$ Coverage $]$
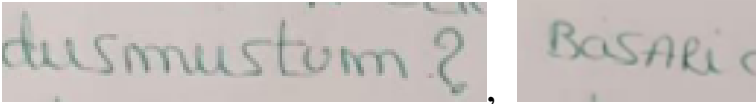

When reductions are analyzed, it is seen that letter and syllable reductions occur in the style of writing as heard.

S1 - $\S 1$ reference coded [0,23\% Coverage]

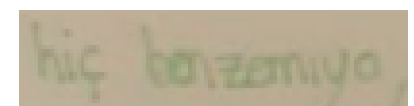

S14 - $\S 9$ references coded $[2,01 \%$ Coverage $]$

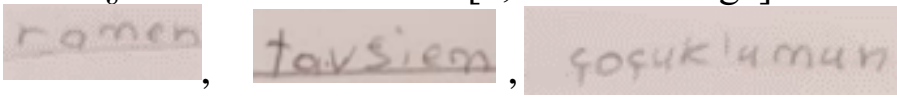

Sometimes, there is a case of not using the buffer consonant letter.

$\underline{\text { S17 }}$ - $\S 1$ reference coded [0,15\% Coverage]

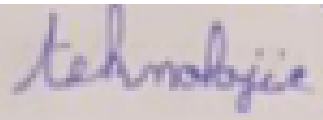

While writing the predicative verbs, a number of reductions were made. Especially in the past tense suffix in which a predicative verb is seen, the auxiliary sound " $y$ " is usually not used.

S13 - $\S 1$ reference coded [0,22\% Coverage]

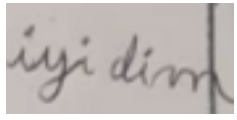

S3 - $\S 1$ reference coded $[0,22 \%$ Coverage $]$

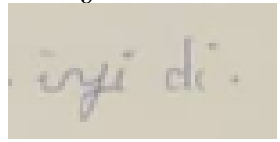

Looking at the additions, two types of addition arise. As the first one, the use of local dialect properties can be expressed.

S11 - $\S 1$ reference coded $[0,31 \%$ Coverage $]$

Secondly, it is seen that there are errors caused by not knowing how to write what is heard during the writing.

S5 - $§ 1$ reference coded $[0,10 \%$ Coverage $]$ 
S7 - $\S 1$ reference coded [0,30\% Coverage]

\section{eolenvime.}

Students are generally considered successful in using conjunctions. However, problems about the "ve" conjunction come to the fore. These were mostly used where commas should be used or after the verbal suffixes.

S1 - $\S 1$ reference coded [1,26\% Coverage]

used, rather created as an indefinite noun phrase.

S2 - $\S 1$ reference coded [0,21\% Coverage]

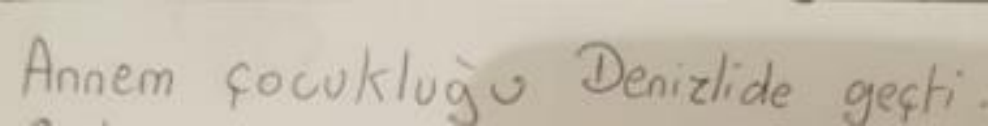

Comparison and supremacy structures were created from time to time using both of them in a mixed form, and sometimes, they were used interchangeably.

S16- $\S 1$ reference coded [0,44\% Coverage]

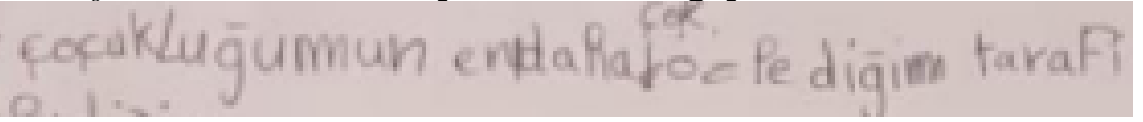

Possessive suffix errors are rather in the form of not using the suffix.

S10 - $\S 1$ reference coded [0,48\% Coverage]

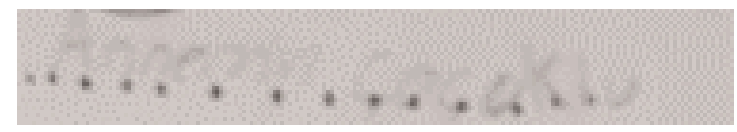

\section{Misspellings}

As a result of the content analysis, the codes were gathered in the second place in the categorical main heading "misspellings" (37.26\%) and a total of 622 codes were formed under this heading. 


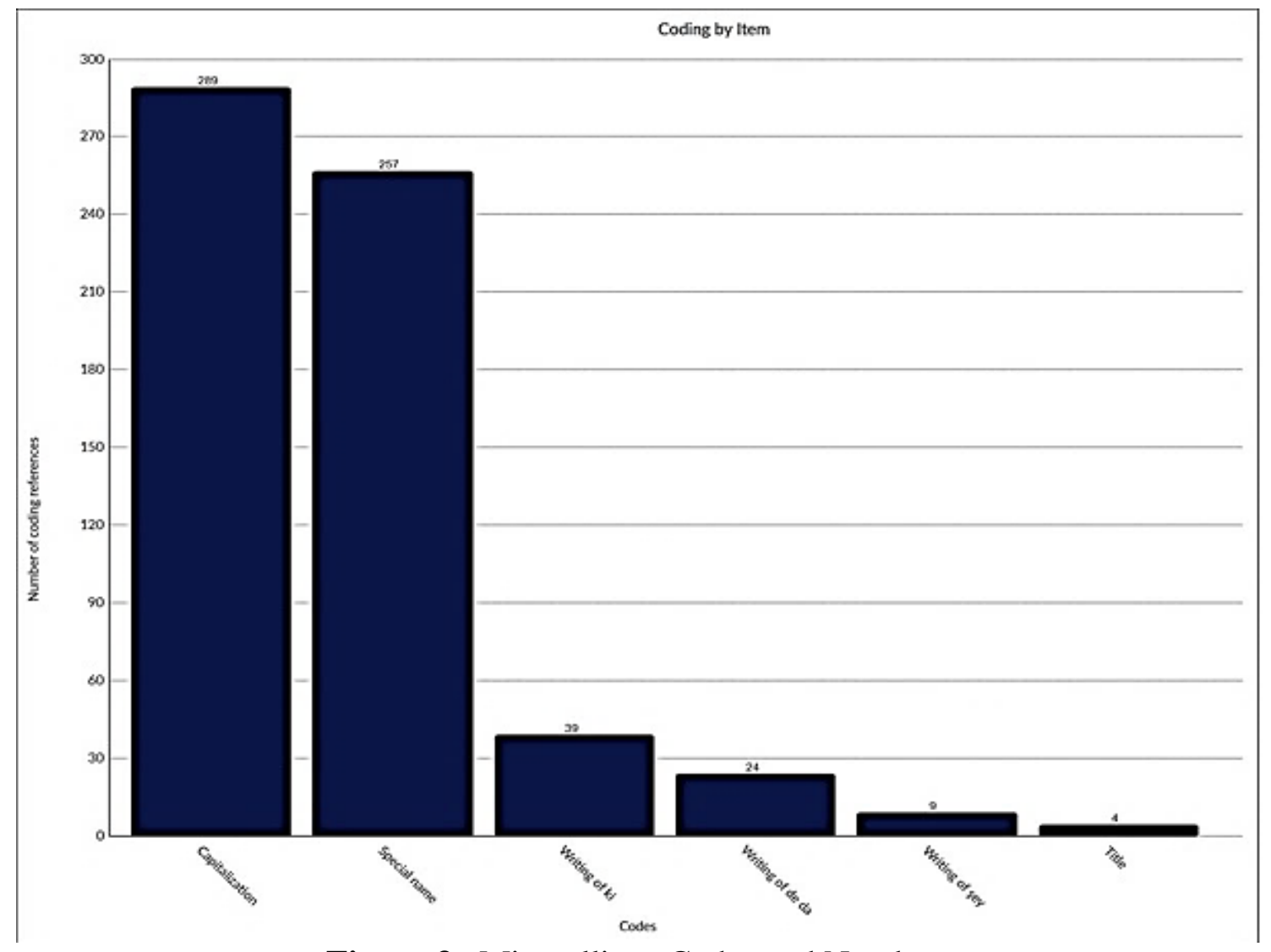

Figure 3. Misspellings Codes and Numbers

When the main code headings are viewed, it is seen that the problems of capitalization, writing special names, writing "ki", writing "de, da", writing the word "şey", and writing headings come to the fore.

The fact that the most errors occur in capitalization signifies a confusion. Many students experienced this confusion (eighteen people). It is seen that some students prefer uppercase instead of lowercase letters while writing in lowercase.

$\underline{\text { S11 }}$ - $\S 1$ reference coded $[0,21 \%$ Coverage $]$

$\underline{\text { S7 }}$ - $§ 2$ references coded $[0,59 \%$ Coverage $]$

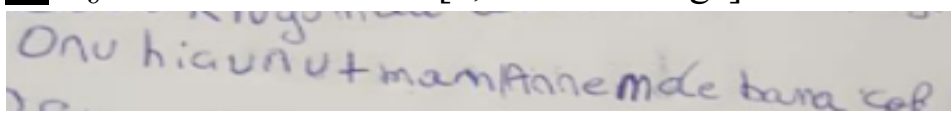

In some uses, there is a mixed spelling in the form of a few uppercase letters and a few

$\underline{\text { S6 }}$ - $§ 14$ references coded $[5,81 \%$ Coverage $]$

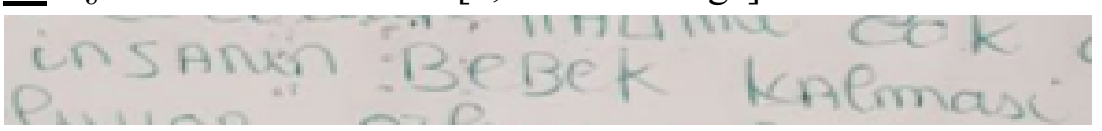

This form of use sometimes appears after some punctuation, such as commas.

$\underline{\text { S2 }}$ - $\S 1$ reference coded [0,28\% Coverage]

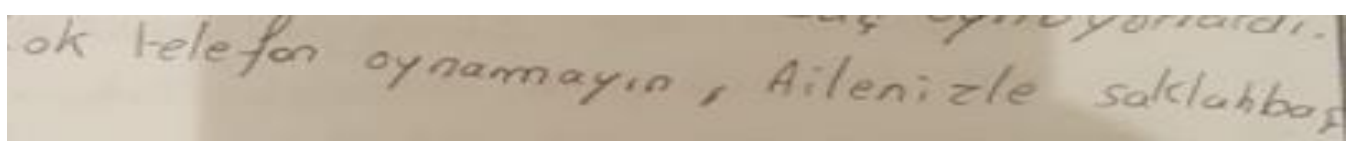


The second most common error was with the use of special names, but the use of special names is the same, despite minor differences in all the languages. It is thought that the high number of errors in this regard indicates that similar errors were made in the second language. $\underline{\text { S19 }}$ - $\S 3$ references coded [0,79\% Coverage]

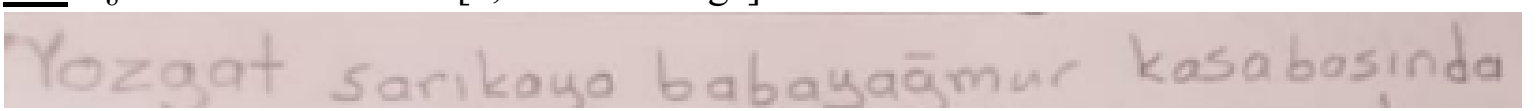

$\underline{\text { S22 }}-\S 3$ references coded $[0,74 \%$ Coverage $]$

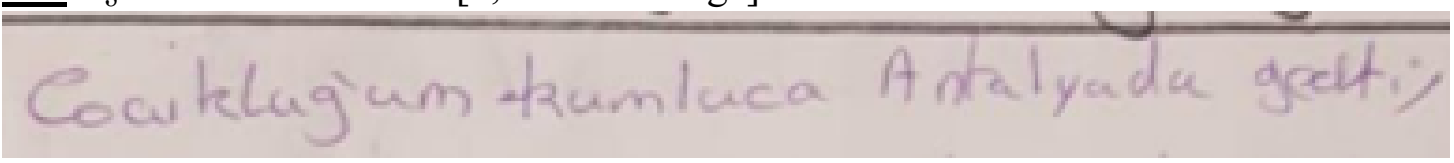

Some of these errors were made by students who did not know the uppercase or lowercase form of the letter, even though they knew the rules about special names, or because of handwriting. In the example below, the student's separation of the in flexional suffix with the apostrophe in a special name indicates that he knows that the word is a special name, but since he does not know the uppercase (Y) form of the letter, or it was considered misspelling because it was handwritten in lowercase (y).

S21 - $§ 4$ references coded $\lceil 1.09 \%$ Coverage $\rceil$

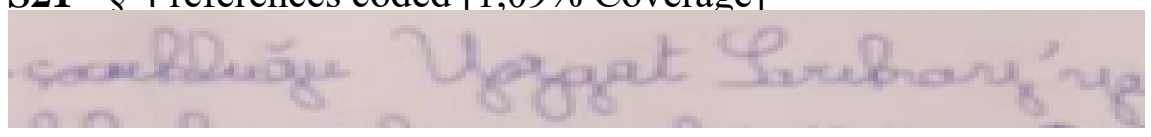

Errors were made in writing "ki", which is a conjunction, suffix, or relative pronoun.

S23 - $§ 1$ reference coded $\lceil 0.25 \%$ Coverage $\rceil$

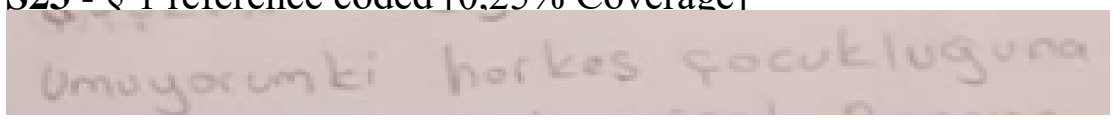

$\underline{\text { S16 }}$ - $§ 1$ reference coded $[0,19 \%$ Coverage $]$

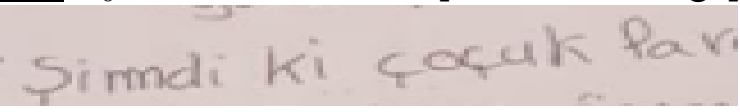

A similar misuse is observed in the letter "de, da", which is a suffix of presence or conjunction.

$\underline{\text { S19 }}$ - $\S 2$ references coded $[0,48 \%$ Coverage $]$

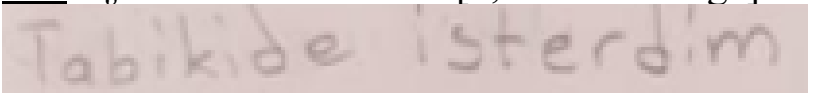

$\underline{\text { S23 }}-\S 1$ reference coded $[0,27 \%$ Coverage $]$

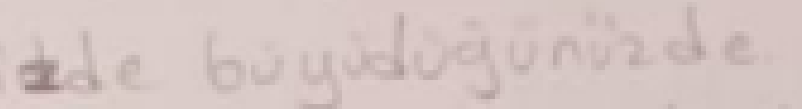

\section{Inter-language (From French to Turkish) transfers}

As a result of the content analysis, the codes were gathered in the third place under the main heading "Inter-language (From French to Turkish) transfers" (14.85\%) and a total of 248 codes appear under this heading. 


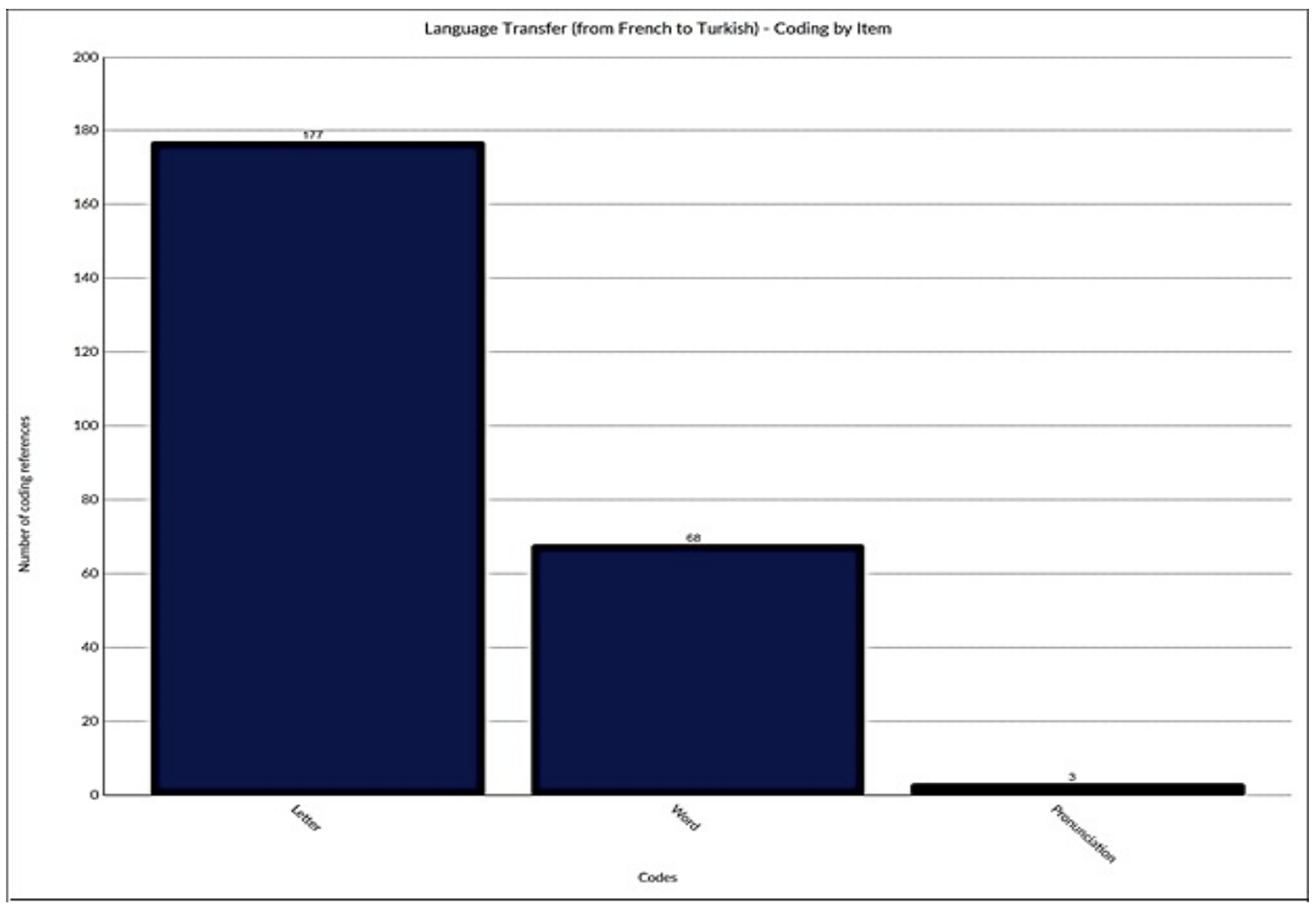

Figure 4. Inter-language (From French to Turkish) Transfer

When the main code headings are viewed, it is seen that transfers to Turkish are accomplished in the headings of letters, words and pronunciation. It is seen that the most transfers are in the form of taking letters or borrowing words (using French instead of the Turkish equivalent of the word). It is seen that the students sometimes mix the spelling of two languages or use the two languages in common. In some letters, errors were made more often. The first one is the letter "m" (eight students). Since the letter in question was written as in handwriting, it seems like it has the letter "n" beside it.

S2 - $\S 4$ references coded $[1,46 \%$ Coverage $]$

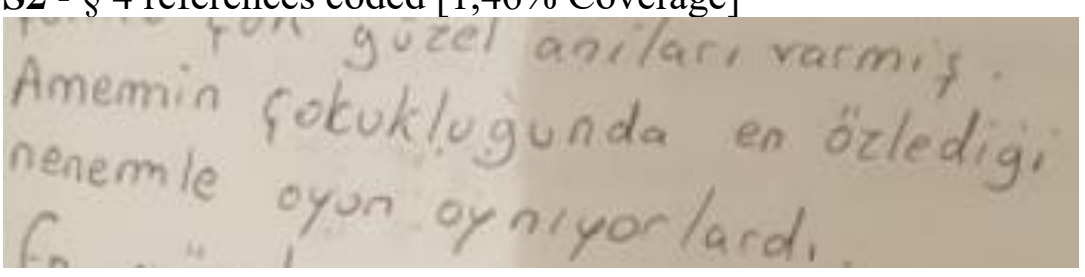

When the lowercase "l" was written in handwriting and used similarly, it was written like the letter "P".

$\underline{\text { S5 }}-\S 1$ reference coded $[0,18 \%$ Coverage $]$

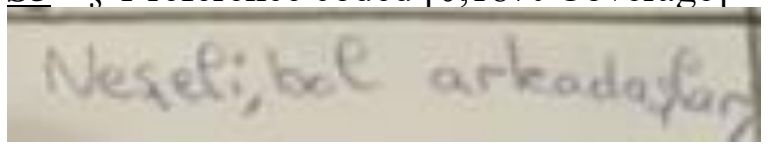

Another letter transfer took place on the letter "e" whose sound value in Turkish is different from that of French. In response to the "e" sound in Turkish, some students used the letter format called "l'accent aigu" in the French accents section.

$\underline{\mathbf{S 1 1}}-\S 1$ reference coded $[0,20 \%$ Coverage $]$ 
In some cases, the sound equivalent of the letter " $k$ " in Turkish is met by writing "c" as in French.

$\underline{\text { S12 }}$ - $§ 1$ reference coded $[0,59 \%$ Coverage $]$

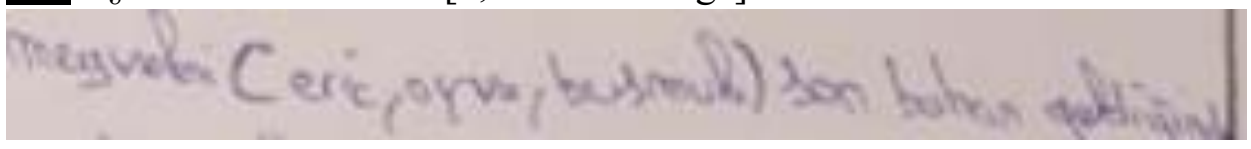

Although it is in Turkish, it was accepted as if there was no uppercase "í", and instead, "l" was used as in French.

S12 - $\S 1$ reference coded $[0,12 \%$ Coverage $]$

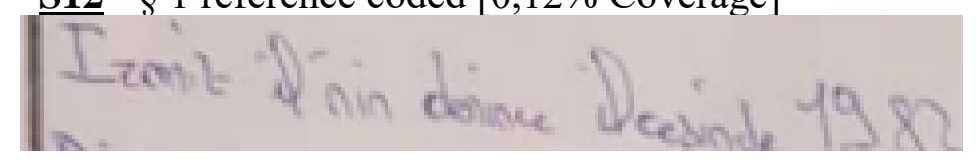

When word transfers are viewed, although it is not as characteristic as using letters, it is seen that it takes place in the form of writing the French equivalent instead when the Turkish one is not known.

$\underline{\mathbf{S 1 7}}-\S 1$ reference coded $[0,62 \%$ Coverage $]$

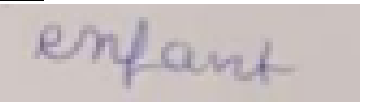

The second obvious use is that the word is written as it is written in French or close to it.

$\underline{\text { S7 }}$ - $\S 1$ reference coded $[0,66 \%$ Coverage $]$

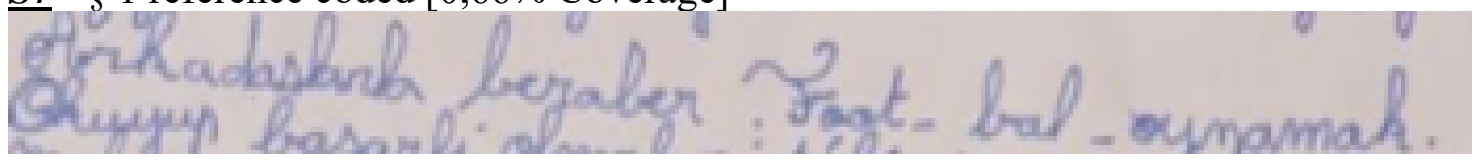

In some examples, an error was made by writing down the pronounced version of the word in French.

$\underline{\mathbf{S 1 4}}-\S 1$ reference coded $[0,47 \%$ Coverage $]$

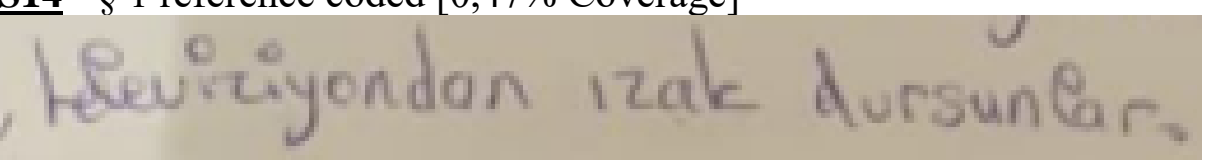

\section{Punctuation Errors}

As a result of the content analysis, the codes were gathered in the fourth place under the main heading "punctuation errors" (8.56\%), and 143 codes in total appear under this heading 


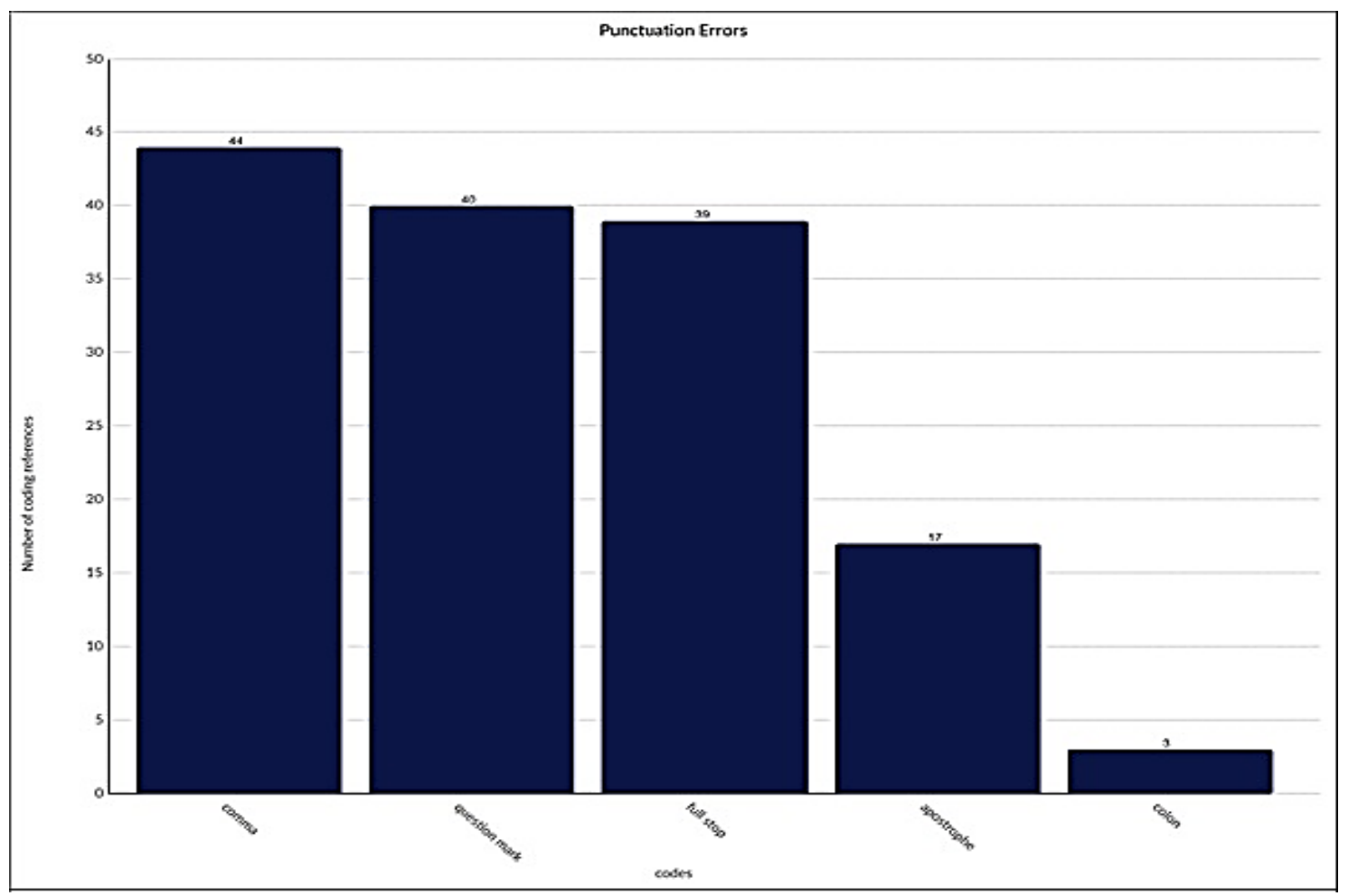

Figure 5. Punctuation Errors

Main code headings followed a line as a comma, question mark, full stop, apostrophe, and colon. There are punctuation marks in every language, and it should be stated that these marks, when used correctly in all languages, play an important role in ensuring the integrity of the meaning. Despite some differences, these marks are thought to have basically similar uses, and thus, the least errors occur under the heading of punctuation marks. Despite the errors, presence of very successful examples points at the importance given to punctuation. It is seen that the errors on commas are led by using a comma after the words 'yes' or 'no', which are used depending on the sentences after them and mean rejection-acceptance.

S8 - $§ 1$ reference coded $[0,98 \%$ Coverage $]$

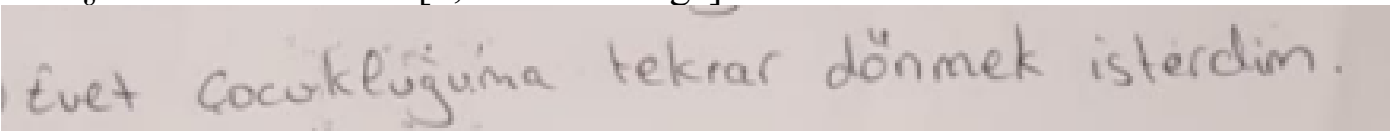

In some writing examples, there are errors resulting from the out-of-rule or unnecessary use of a comma.

$\underline{\text { S12 }}$ - $\S 1$ reference coded $[0,29 \%$ Coverage $]$

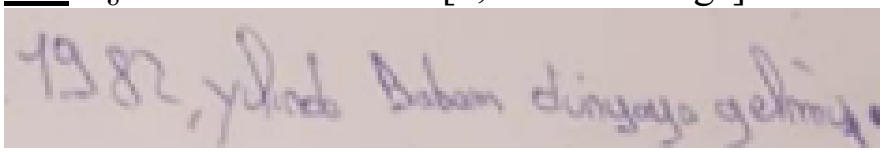

In some examples, the rule of placing commas between coordinated statements listed in a similar manner in many languages has been violated.

$\underline{\text { S19 }}$ - $\S 1$ reference coded $[0,35 \%$ Coverage $]$

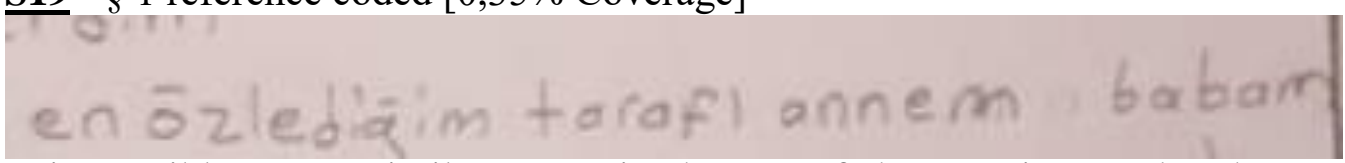

It is possible to see similar errors in the use of the question mark. The examples mostly 
emerge in the form of not knowing where to use a question mark or sometimes mistaking it with the exclamation mark.

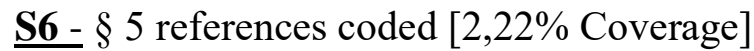

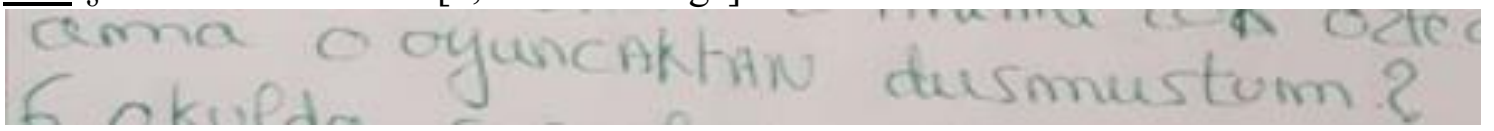

The fact that the full stop that was not put at the end of the sentence caused an error in many writing examples.

$\underline{\text { S10 }}$ - $\S 1$ reference coded $[0,42 \%$ Coverage $]$

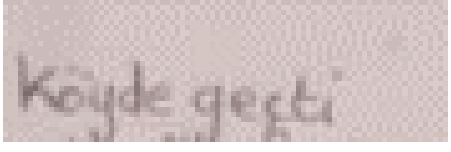

It is also possible to come across examples where the full stop was mixed with commas.

S22 - $\S 1$ reference coded $[0,38 \%$ Coverage $]$

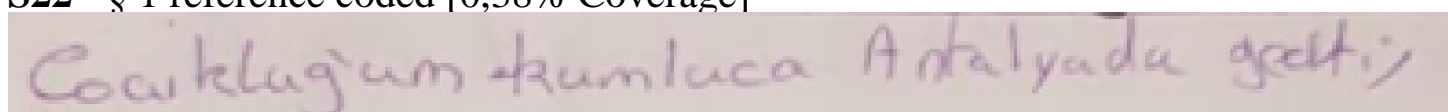

It is noteworthy that the apostrophe errors are less in number than other punctuation marks. Errors are often seen in the form of not separating the suffixes brought to the country and city names.

S11 - $\S 1$ reference coded $\lceil 0,30 \%$ Coverage $]$

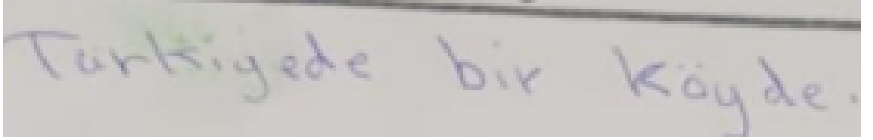

In some cases, an out-of-rule and unnecessary use of apostrophe is observed.

$\underline{\text { S25 }}-\S 1$ reference coded $[0,24 \%$ Coverage]

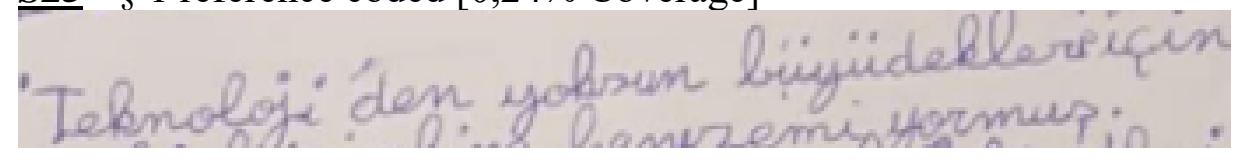

In some places, it has been determined that the apostrophe used to separate the suffixes brought to the numbers was not used.

$\underline{\text { S21 }}-\S 1$ reference coded $[0,18 \%$ Coverage $]$

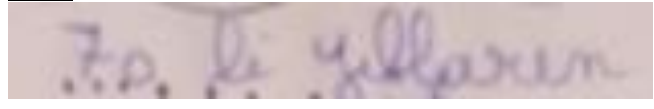

The use of colons is not often included in writing examples. This situation is thought to arise from not knowing where to use the aforementioned mark. In some examples, it is seen that colons were not used where they should have been used.

$\underline{\mathbf{S 2 3}}-\S 1$ reference coded $[0,15 \%$ Coverage $]$

However, it is possible to see examples where colons were used successfully, albeit very little.

$\underline{\text { S20 }}$ - $\S 1$ reference coded [2,23\% Coverage]

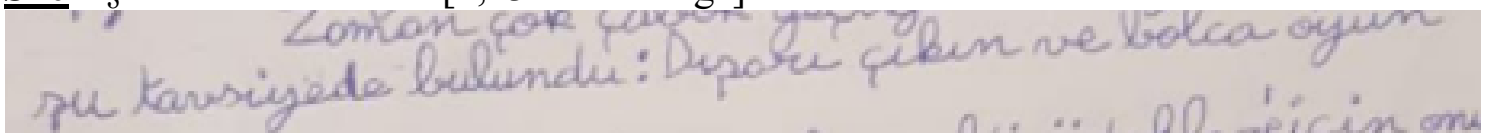




\section{Student Error Density}

As a result of the content analysis, it was evaluated that it would be wrong to make inferences about the students only by considering the number of students' errors. It was then concluded that it would be more accurate to calculate student errors by using the total number of words used in the document to make some inferences. For example, it is thought that the "twenty" errors made by a student with forty-two words (S3) and a student with two-hundred and eighty-nine words (S18) in total should not be evaluated in the same proportion. For this reason, the following formula is used for the error density.

$$
\text { student error density }=\frac{\text { total error code number detected } \mathrm{x} 100}{\text { total word number used in the document }}
$$

The formula was applied to all the papers and the following results were obtained. Notable issues have been interpreted and given.

Table 3. Error Densities of Students

\begin{tabular}{|c|c|c|c|c|}
\hline Persons & $\begin{array}{l}\text { Total Number of Words } \\
\text { Used in the Document }\end{array}$ & $\begin{array}{l}\text { Total Number of } \\
\text { Error Codes }\end{array}$ & Error Density (\%) & Rank \\
\hline S1 & 243 & 36 & 14,81 & 22 \\
\hline S2 & 127 & 42 & 33,07 & 13 \\
\hline S3 & 42 & 22 & 52,38 & 9 \\
\hline S4 & 122 & 22 & 18,03 & 19 \\
\hline S5 & 78 & 50 & 64,1 & 6 \\
\hline S6 & 191 & 338 & 176,96 & 1 \\
\hline S7 & 92 & 67 & 72,82 & 5 \\
\hline S8 & 209 & 28 & 13,39 & 23 \\
\hline s9 & 161 & 34 & 21,11 & 17 \\
\hline S10 & 36 & 22 & 61,11 & 7 \\
\hline S11 & 44 & 22 & 50 & 10 \\
\hline S12 & 226 & 83 & 36,72 & 12 \\
\hline S13 & 34 & 28 & 82,35 & 3 \\
\hline S14 & 189 & 100 & 52,91 & 8 \\
\hline S15 & 95 & 95 & 100 & 2 \\
\hline S16 & 230 & 70 & 30,43 & 14 \\
\hline S17 & 169 & 139 & 82,24 & 4 \\
\hline S18 & 289 & 20 & 6,92 & 24 \\
\hline S19 & 291 & 56 & 19,24 & 18 \\
\hline S20 & 327 & 22 & 6,72 & 25 \\
\hline S21 & 264 & 58 & 21,96 & 16 \\
\hline S22 & 258 & 124 & 48,06 & 11 \\
\hline S23 & 376 & 97 & 25,79 & 15 \\
\hline S24 & 308 & 50 & 16,23 & 20 \\
\hline S25 & 294 & 44 & 14,96 & 21 \\
\hline Total & 4695 & 1669 & 35,54 & 25 \\
\hline
\end{tabular}

When the error densities are analyzed, it is seen that the highest rate is in students with codes S6 (176.96\%) and S15 (100\%). It is understood that the lowest rate belongs to S20 (6.72) and S18 (6.92) students. When the paper of the student with the code S15 was checked, it was 
determined that everything was written in French. The fact that the student cannot write in Turkish at all is considered as not knowing Turkish at all. The code comparison of the students S20 and S18 with the least error codes is made below because the common error codes of these two students are thought to be important for teachers and researchers.

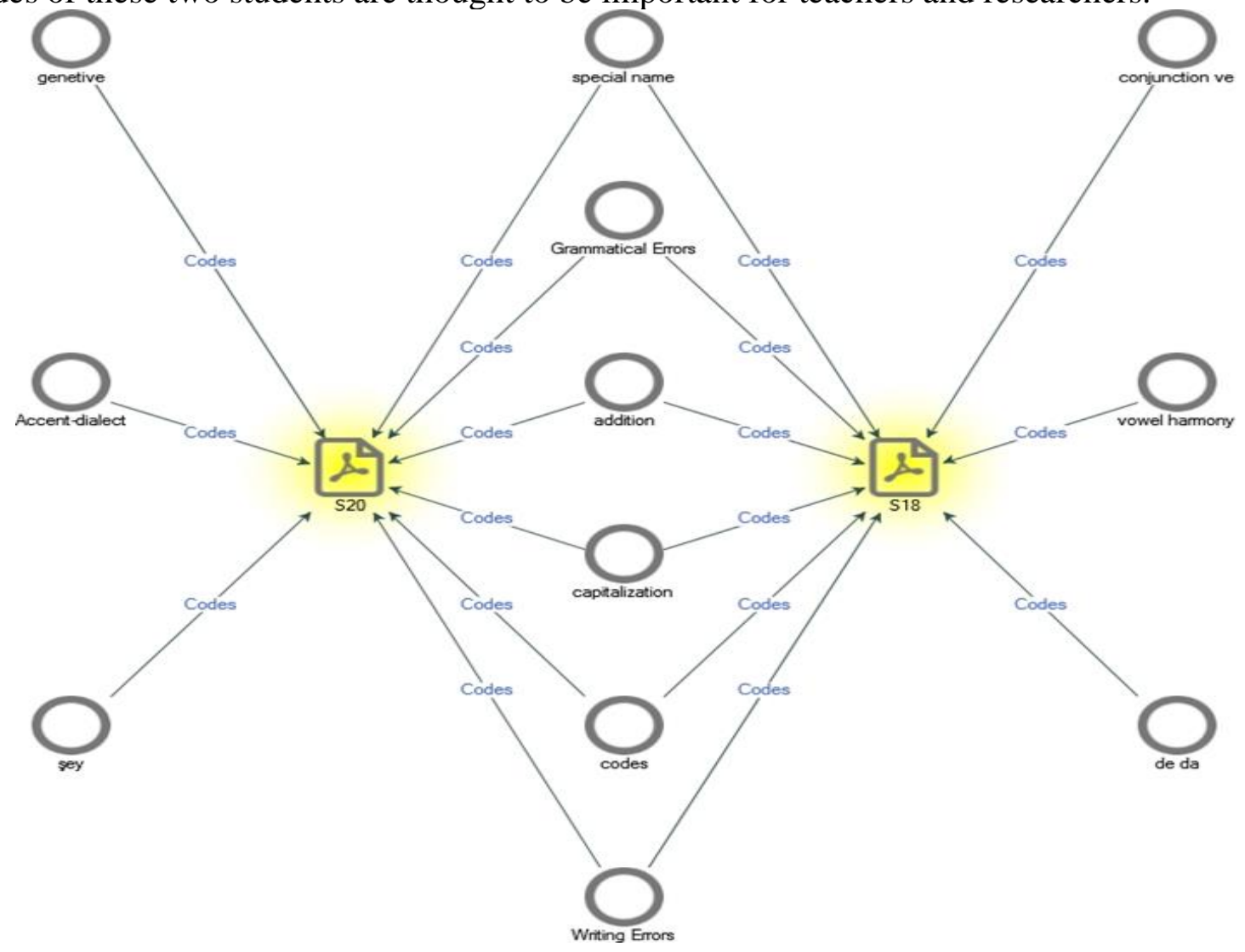

Figure 6. Error Code Comparison of the Students S18 and S20

When the error codes are viewed, it is seen that common errors are about special names, addition and capitalization. It is understood that even the most successful students made errors in this regard. In addition, it is seen that the student numbered S20 carries the local dialects to the article, and that he has deficiencies in the separate writing of the genitive suffix and the word "şey". It is seen that S18 does not pay attention to the vowel harmony, although not so often, in his paper. It is thought that this situation should be evaluated as an unintended error instead of an error because it was not repeated and transferred to similar situations. Besides, it appears that he made errors in using unnecessary conjunctions, "ve", and writing the "de, da" conjunction separate. It is believed that another comparison should be made between the student with the most error codes and the student with the least error codes. It is important to note under which headings the error code difference occurs. 


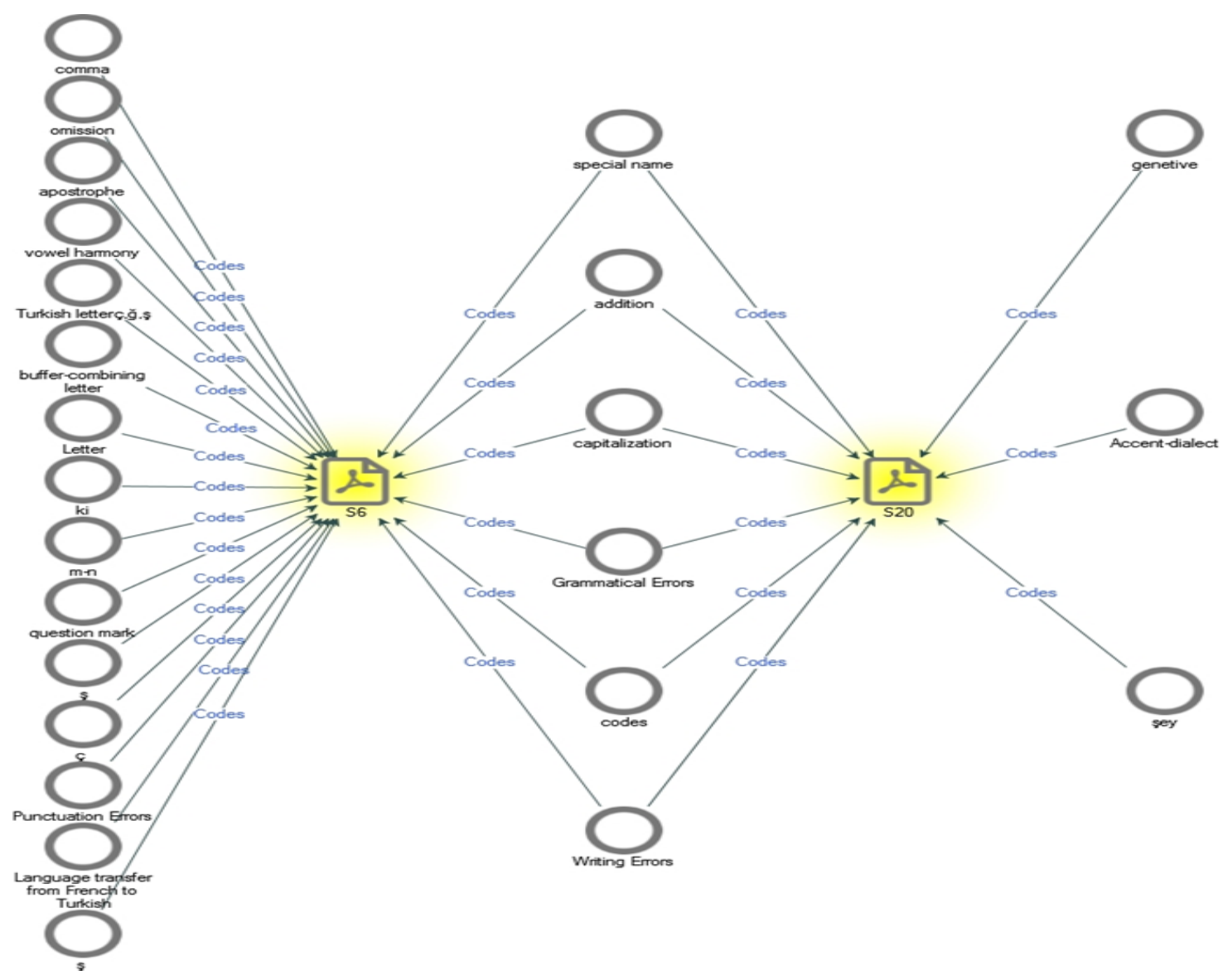

Figure 7. Error Code Comparison of the Students S6 and S20

In the code comparison of the student with the most error codes and the student with the least error codes, it is seen that S6 also made errors under many headings besides the common errors related to the use of special names, addition and capitalization. These headings consist of comma, reduction, apostrophe, vowel harmony, consonants specific to Turkish (ç, $\breve{g}$, ş), blending letters, writing "ki", writing m-n, question mark, transfer from French to Turkish (letter, word, pronunciation). These matters are considered to be important issues that should be emphasized while teaching.

\section{Discussion and conclusion}

Considering the errors made by the students, it is seen that the codes are mostly concentrated in the writing of consonants (ç, $\breve{g}$, ş) specific to Turkish and vowels (ü, ö, 1 ) which are in Turkish but not in French. It is observed that the difficulties in writing Turkish letters are overcome with the closest letters available in the second language, and the vowel harmony rule cannot be used properly despite the vowels in Turkish. A study by Arslan \& Sasmaz (2016) on the mother tongue use of Turkish children whose mother tongue is Turkish and who live in Bosnia and Herzegovina contains similar findings. As a result of the research, it was concluded that misspellings of the letters specific to Turkish are at a high level, students cannot use these letters or do not know how to use them even if they use them, so they need to constantly ask help from their families. In addition, when the results of the research conducted by Halitoglu (2020), who examines the writing samples of Turkish children living in the Netherlands and whose mother tongue is Turkish, it is understood that the most common errors are the problems of the vowel harmony rule $(30 \%)$ that are specific to the language structure of Turkish. It is seen that the problems of writing the letters specific 
to Turkish comes second $(21.15 \%)$. The reason can be the fact that the rules of Turkish vowel harmony were not known by the students and they learned the mother tongue incompletely, because it is observed that the most common errors made by a foreign student who did not speak Turkish at all were the vowel-consonants and vowel harmony rules specific to Turkish (Ciftci \& Demirci, 2019; Er et al., 2012; Erdil, 2017).

The fact that a student whose mother tongue was Turkish made errors pertaining to Turkishspecific letters, constantly asked questions to his parents about it and the fact that a foreigner's making similar errors who was learning Turkish as a second language indicates that there was a significant lack of knowledge and practice. This indicates the danger of replacement of the second language by the mother tongue and the mother tongue by the second language, which is widely spoken in the community resided in (Deniz \& Uysal, 2010). Moreover, despite the fact that mother tongue classes are indeed held in France and that there exists the assignment of Turkish and Turkish Culture teachers the very situation points at the presence of certain problems. As a matter of fact, when the studies on the mother tongue teaching problems in France are examined, the reasons such as the students' non- attendance in the language classes, the negativities brought about by the mixed class approach, unsuitability of the course materials for the level, the lessons delivered inefficiently as to the hours allocated, and the negative language policies of the related state standout (Akinci, 2012; Celik \& Gulcu, 2016; Gungor, 2015; Sonmez, 2018). It is understood that these problems directly affect Turkish teaching process and decrease the quality of teaching.

Similarly, making errors in reductions or additions due to writing as what is being heard by the students indicate lack of knowledge and practice. However, it seems that these deficiencies do not apply to all the participants of the study, some papers have a very high success in spelling, and the error density of these students is also very low. It is possible to explain this by students' having experienced a well-qualified learning process in their family, in school or in courses, unlike others, because those students did not make the errors made commonly by even their peers in Turkey. For example, Akkaya (2013) examines what kind of mistakes and errors sixth grade students in Turkey make in their writing, and concludes that "de, da" conjunction or suffix writing lead the errors. Contrary to this situation, when the articles were examined within the scope of the research, it was observed that each paper presented at least three examples of correct use in writing "de, da" in the papers of students numbered S1, S18 and S20 and that there was no error in this regard. The fact that even their peers in Turkey often make errors indicates that their individual learning is far superior to their peers.

However, on the contrary, it has been determined that language transfer errors are noteworthy in many students. It is seen that especially some students made a lot of errors in borrowing letters or words, using mixed languages, and that a student wrote completely in the second language (S15). The students confuse the features of the two languages for different reasons, or when they have difficulty, they seek the help of the other language. Research shows that this can be evaluated as common errors in bilingual students (Bilgic, 2016; Flanagan \& Hirokowa, 2018; Karim \& Nassaji, 2013; Sebba, 2012; Watcharapunyawong \& Usaha, 2012). Bilingual children have a richer concept and mental flexibility than monolingual children (Ricciardelli, 1992; Rodriguez, 2013). With this flexibility, students gain the opportunity to take advantage of the other language when they are coerced in a language, automatically transmit their second-language equivalent, rather than the actual word or letter they do not know in their mother tongue. This situation, which is very useful for students in terms of concept acquisition, linguistic and cognitive development, is in fact a disadvantage in terms of 
writing (errors such as mixed writing, word and letter transfer). Competency in writing and other language learning areas is an important issue in order to reduce the errors in this matter, because, as the competence in the language increases, the deficiencies will decrease and the application to non-linguistic elements will decrease. Otherwise, there will be a semicompetent language use, that is, semi-bilingualism in both languages (Hansegard, 1968). Semi-bilingualism refers to a language learning process that is incomplete in both languages. The children in this situation encounter an increase in the effect of the second language used in that country over time and gradual decrease in their mother tongue. Ultimately, one or a few generations later, it is an inevitable result that the mother tongue disappears. Research on the language use of Turkish children in France supports this fact. According to the research conducted by Kizilyurek (2002) on the language use of Turkish children in France, 92.1\% of the children stated that they spoke French more easily while only $75 \%$ said that they spoke Turkish more easily. Considering the answers given to the question directed about the writing skill in the same research, the rate of those who wrote French easily was $76.6 \%$, while the rate of those who wrote Turkish easily remained at $21.8 \%$. Ince (2011) states that those, $75 \%$, who say they speak Turkish easily are not reliable because there is a serious decrease in the rates of the writing skills of the same people. As of today, it is possible to state that the competence of the mother tongue use of Turkish children living in France has weakened, based on past research and the results of our research.

According to the findings of the studies, bilingual children may make a broad range of spelling and punctuation errors in both languages, depending on their native language proficiency and target language competence, and there is no holistic view on this issue. The students who participated in our study made lots of errors with punctuation, writing, and spelling. Hardiyanti (2017) claims that bilingual children make mistakes in writing when it comes to relevance, organization, vocabulary, and grammar, based on his study. Similarly, according to Griswold (2017), bilingual children make more grammatical errors than monolingual children and have a greater need to learn to write than monolingual children. Unlike these results Kaushanskaya (2018) concluded that bilinguals have higher levels of comprehension and vocabulary learning than monolinguals. In the study, it is stated that bilingual learners can encode information related to new words at a deeper level of understanding and produce words and monolinguals. In a study of monolingual and bilingual children, Clellen et al. (2008) found that bilinguals did not have any deficits in terms of subject and predicate use as compared to monolinguals. Bilinguals outperform monolinguals in terms of language use in essay organization, according to Ngwa (2012). As a result, it is claimed that bilinguals do not have a general viewpoint on spelling mistakes; however, bilinguals can be more competitive than monolinguals in terms of comprehension and comprehension skills in certain areas of writing.

When the results of the research are evaluated, it is possible to make some recommendations in order to prevent the incomplete or insufficient mother tongue learning and to ensure competence in the use of the mother tongue.

\section{Recommendations}

- Parents should be made aware of various education and training activities on mother tongue and culture through educational consultancy or embassies.

- The writing learning area should be supported to include speaking, reading and listening areas. 
- Environments and activities where students will be exposed to correct Turkish should be created.

- Action plans should be prepared by educational consultancies to solve the problems reported in? of mother tongue research conducted in France.

- Various levels of reading and writing materials and activities should be developed for students.

- Supporting mother tongue teaching activities should be carried out through organizations such as Turkish associations

\section{References}

Ahmad, S., Hassan, M., Qureshi, M. B., Qureshi, M. I. (2015). Effectiveness of direct feedback method of error treatment used for urdu EFL learners at intermediate level in Pakistan. American Research Thoughts, 1 (10), 2315-2329.

Akinci, M. A. (2007). Fransa'da Turkce ana dili egitimi ve iki dilli Turk cocuklarinin dil becerileri [Turkish mother tongue education in France and language skills of bilingual Turkish children], II. Avrupa Turk Dili Bilgi Soleni [II. European Turkish Language Information Meeting], University of TOBB Economy and Tecnology, Ankara.

Akinci, M. A. (2012). Ben zaten Turkce biliyorum, Turkce derslerine niye gideyim ki? Fransa'da Turkcenin ogretilmesinde son durum world Turkic forum. Turkic Council, Turkic Diaspora and Socio-Economic Cooperation, Publisher: TASAM, .361-376.

Akkaya, A. (2013). 6. Sinıf ogrencilerinin yazim yanlislari sikligi ve yazim yanlislarinin nedenlerine iliskin ögretmen gorusleri.Turkish Studies, 8 (4), 33-52.

Ardila, A., Garcia, K., Garcia, M. (2017). Writing and reading knowledge of Spanish/English second-generation bilinguals. Read Writ, 30, 387-400.Akkaya, A., Doyumgac, I. (2020). Turkce egitiminde temel kavramlar. Ahmet Zeki Guven (Ed.), Turkce egitimine genel bir bakis icinde (s. 21-38). Ankara: Pegem Akademi.

Alsamadani, H. A. (2010). The relationship between Saudi EFL students' writing competence, L1 writing proficiency, and self-regulation. European Journal of Social Sciences, 16, 53-63.

Arslan, M.; Sasmaz, A. (2016). Mother language usage and cultural in terms problems face with of Turkish children living abroad: the case of Bosnia and Herzegovina. International Journal of Languages' Education and Teaching, 4 (1), 180-195.

Baldik Y. (2018). Ana dili Turkce olmayan gocmen topluluklarin egitim sistemine katiliminda Turkce ogretiminin onemi [The importance of teaching Turkish in the participation of immigrant communities whose mother tongue is not Turkish in the education system] (Master Thesis). University of Nevsehir Haci Bektas Veli, Social Sciences Institute, Nevsehir.

Berninger, V. W. (2009). Highlights of programmatic, interdisciplinary research on writing. Learning Disabilities Research \& Practice, 24, 69-80.

Bilgic, M. (2016). Bati Avrupa'da iki dilli Turk cocuklarinin yazili Turkce kelime sikliklari: Fransa ornegi (Master Thesis). Sakarya Universitesi Egitim Bilimleri Enstitusu, Sakarya.

Bowen, G. A. (2009). Document analysis as a qualitative research method. Qualitative Research Journal, 9 (2), 27-40.

Brown, Douglas H. (2001). Teaching by Principle. San Fransisco: Second Edition.

Celik, Y.; Gulcu, I. (2016). Yurtdisinda kullanilan Turkce ve Turk kulturu ders kitaplarina yonelik ogretmen gorusleri. Bartin Universitesi Egitim Fakultesi Dergisi, 5 (2), 287296. 
Cetinkaya, G. (2015). Yanlis cozumlemesinin: yabanci dil olarak Turkçe oğrenen B2 duzeyindeki oğrencilerin yazili metinlerine ilişkin gorunumler. International Journal of Languages' Education and Teaching, 3 (1), 164-178.

Ciftci, O., Demirci, R. (2019). Alfabe farkliliklarinin yabancilara Turkce ogretimindeki etkisi. Turuk Uluslararasi Dil, Edebiyat ve Halkbilimi Arastirmalari Dergisi, 7 (19), 96-127.

Clellen, V. F., Simon-Cereijido, G., Wagner, C. (2008). Bilingual children with language impairment: a comparison with monolinguals and second language learners. Applied psycholinguistics, 29 (1), 3-19.

Creswell, J.W. (2013). Qualitative inquiry and research design: Choosing among five approaches (3rd ed). Thousand Oaks, CA: Sage Publishing.

Deniz, Y.; Uysal, A. (2010). Avrupa dilleri ogretimi ortak cerceve metni ve yurt disindaki Turk cocuklari icin Turkce ve Turk kulturu ogretim programi. Turkluk Bilimi Arastirmalari, 27, 239-261.

Doff, A. (1993). Teach English. Cambridge: Cambridge University Press.

Dweik, B. S., Abu Al Hommos, M. D. (2007). The effect of Arabic proficiency on the English writing of bilingual- Jordanian students. Online Submission, 1-21.

El-Aswad, A. A. (2002). A study of the $l l$ and $l 2$ writing processes and strategies of Arab learners with special reference to third-year Libyan University students (Unpublished Doctoral Dissertation). Newcastle University, England.

Er, O., Bicer, N. , Bozkirli, K . (2012). Yabancilara Turkce ogretiminde karsilasilan sorunlarin ilgili alan yazini isiginda degerlendirilmesi. Uluslararasi Turkce Edebiyat Kultur Egitim (TEKE) Dergisi, 1 (2), 51-69.

Erdil, M. (2017). Turkce okutmanlarinin yabanci ogrencilerin Turkce yazma becerisine karsi oznel algilari. Turkish Studies, 12 (28), 281-306.

Evans, J. (2001). Introduction: learning and teaching the complexities of writing in Janet Evans (ed.), writing in the elementary classroom: a reconsideration. Portsmout, $\mathrm{NH}$ : Heinemann.

Ferris, D. (1999). The case for grammar correction in 12 writing classes: a response to Truscott (1996). Journal of Second Language Writing, 8 (1), 1-11.

Flanagan, B.; Hirokawa, S. (2018). An automatic method to extract online foreign language learner writing error characteristics. International Journal of Distance Education Technologies, 15-30.

Gascoigne, C. (2004). Examining the effect of feedback in beginning L2 composition. Foreign Language Annals, 37, 71-76.

Gass, S.; Selinker, L. (2001). Second language acquisition: an introductory course. (2nd ed.). Mahwah, NJ: Lawrence Erlbaum.

Gort, M. (2006). Strategic codeswitching, inter-literacy, and other phenomena of emergent bilingual writing: Lessons from first grade dual language classrooms. Journal of early childhood literacy, 6 (3), 323-354.

Graham, S. (2008). Research on writing development, practice, instruction and assesment: introduction to a special issue of reading and writing. Read Write, 21, 1-2.

Graham, S.; Perin, D. (2007). A meta-analysis of writing instruction for adolescent students. Journal of Educational Psychology, 9 (9), 445-476.

Griswold, O. (2017). Verb errors of bilingual and monolingual basic writers. The Catesol Journal, 29 (2), 109-137.

Gulbahar, Y.; Alper, A. (2009). Ogretim teknolojileri alaninda yapilan arastirmalar [Research in the field of instructional technology]. Ankara University Journal of Educational Sciences, 42 (2), 93-111.

Guler, A., Halicioglu, M. B., Tasgin, S. (2015). Sosyal bilimlerde nitel arastirma (2th Press)[Qualitative research in social sciences]. Ankara: Seckin Publishing. 
Gunes, F. (2007). Turkce ogretimi ve zihinsel yapilandirma [Turkish teaching and mental structuring]. Ankara: Nobel Publishing.

Gungor, T. (2015). Fransa'da Turkce ve Turk kulturu derslerinin mevcut durumu, ogretim programi ve uygulamada karsilasilan sorunlar. International Journal of Languages' Education and Teaching, 5 (4), 73-84.

Halitoglu, V. (2020). Determination of errors in the writing samples of bilingual students studying in Dutch (the case of Rotterdam) . Journal of Language and Linguistic Studies, 16 (3), 1547-1561.

Hansegård, N. E. (1968). Tvåspråkighet eller halvspråkighet? [bilingualism or semilingualism?]. Stockolm: Aldus series 253, Sweden.

Hardiyanti, R. (2017). Analysis on the difficulties faced by a bilingual child in reading and writing. Advances in Language and Literary Studies, 8 (4),43-49.

Harris, G. J.; Cunningham, H. D. (1994). The Simon and Schuster guide to writing. New Jersey: Prentice Hall, Englewood Cliffs.

Hendrickson, J. M. (1978). Error correction in foreign language teaching: recent theory, research and practice. Modern Language Journal, 62, 387-398.

Hourani, T. M. (2008). An analysis of common grammatical errors in the English writing made by 3rd secondary male students in the eastern coast of the UAE. Retrieved from https://bspace.buid.ac.ae/bitstream/1234/225/1/20050055.pdf

Ince, B. (2011). Yurt disindaki Turk cocuklarinin ana dilleri Turkcede yasadiklari anlatim sorunlari [Expression problems experienced by Turkish children abroad in their mother tongue Turkish]: Example of France (Unpublished Doctoral Dissertation). Istanbul University Institute of Social Sciences, Istanbul.

IOM, (2004). Glossary on migration, available online at http://www.iom.int/jahia/webdav/site/myjahiasite/shared/shared/mainsite/published_d ocs/serial_publications/Glossary_eng.pdf

James, C. (1998). Errors in language learning and use: Exploring error analysis. Essex: Pearson.

James, C. (1998). Errors in language learning and use: Exploring error analysis. Essex: Pearson.

Jared, D., Cormier, P., Levy, B., Wade-Woolley, L. (2011). Early predictors of biliteracy development in children in French immersion: A 4-year longitudinal study. Journal of Educational Psychology, 103 (1), 119-139.

Kalfa, M., Mete, F. (2020). Yurt disinda yasayan iki dilli turk cocuklarla yazma calismasi. Turkish Studies Language and Literature, 233-246.

Karim, K.; Nassaji, H. (2013). First language transfer in second language writing: an examination of current research. Iranian Journal of Language Teaching Research, 1 (1), 117-134.

Kaushanskaya, M. (2018). What can errors tell us about differences between monolingual and bilingual vocabulary learning?. International Journal of Bilingual Education and Bilingualism, 21 (4), 389-404.

Kaweera, C. (2013). Writing error: a review of interlingual and intralingual interference in EFL context. English Language Teaching, 6 (7), 9-18.

Kaya, I. (2008). Avrupali Turkler: misafir iscilikten Avrupa vatandasligina [European Turks: from guest work to European citizenship]. Journal of Eastern Geography, 13 (19), 149-166.

Kizilyurek-Gautier, S. (2002). Les enseignements de langue et culture d'origine en France: chronique d'une mort annoncee? le cas de la langue Turque. memoire de dea sous la direction de monsieur Pierre Encreve (Unpublished MA Dissertation). Ecole Des Hautes Etudes en Sciences Social, Ecole Doctoral de Science du Language, Paris. 
Kocak, O.; Gunduz, R. (2016). Avrupa birligi goc politikalari ve gocmenlerin sosyal olarak icerilmelerine etkisi. Yalova Sosyal Bilimler Dergisi, 6 (12), 66-91.

Kosasih, M. C. (2019). Interlingual and intralingual interferences in English narrative essays written by Indonesian students. International Journal of English Language and Literature Studies, 8 (3), 110-122.

Lanauze, M., Snow, C.E. (1989). The relation between first- and second-language skills: Evidence from Puerto Rican elementary school children in bilingual programs. Linguistics and Education, 1, 323-340.

Lv, F., Chen, H. (2010). A Study of metacognitive-strategies-based writing instruction for vocational college students. English Language Teaching, 3 (3), 136144.

Meyers, A. (2006). Composing with confidence. New York: Pearson Education.

Miles, M. B., Huberman, A. M., Saldaäna, J. (2014). Qualitative data analysis: A methods sourcebook (Third edition.). SAGE Publications, Inc.

Nguyen, T. T. L. (2018). The effect of combined peer-teacher feedback on thai students' writing accuracy. Iranian Journal of Language Teaching Research, 6 (2), 117-132.

Ngwa, N. L. (2012). Language analysis and writing proficiency: a comparative study of LMA and bilingual students of ens yaounde (Dissertation of Graduate). University of Buea, Cameroon.

Nunan, D. (2003). Practical English language teaching. Singapore: McGraw-Hill.

Ortakoylu, S , Satilmis, S , Eyup, B . (2020). Yurt disinda yasayan turk cocuklarina yonelik yapilan arastirmalar uzerine bir analiz calismasi. Ana Dili Egitimi Dergisi, 8 (1) , 87112.

Ozdemir, S. (2016). Individual factors in language use and choise among Turkish people living in Scotland. Turkish Studies-International Periodical for the Languages, Literature and History of Turkish or Turks, 11 (4), 761-782.

Patton, M. Q. (2014). Nitel arastirma ve degerlendirme yontemleri [Qualitative research and evaluation methods]. (M. Butun, S. B. Demir, Translated Ed.). Ankara: Pegem Academy.

Pilanci, H. (2009). Avrupa ulkelerindeki Turklerin Turkceyi kullanma ortamlari, surdurebilme imkânlari ve koruma bilincleri [The environment, sustainability and protection awareness of Turks in European countries]. Bilig. 49, 127-160.

Polad, M. (2018). A Comparative analysis of written errors of Turkish, Azerbaijani and Syrian students in English writing skills. International Journal of Contemporary Educational Research, 5 (2), 64-78.

Rao, P. S. (2019). The significance of writing skills in ell environment. Academicia, 9 (3), 517.

Rattanadilok Na Phuket, P., \& Othman, N. B. (2015). Understanding EFL students' errors in writing. Journal of Education and Practice, 6 (32), 99-106.

Rattanadilok Na Phuket, P., \& Othman, N. B. (2015). Understanding EFL students' errors in writing. Journal of Education and Practice, 6(32), 99-106.

Reyes, I. (2006). Exploring connections between emergent biliteracy and bilingualism. Journal of Early Childhood Literacy, 6(3), 267-292.

Ricciardelli, L. A. (1992). Bilingualism and cognitive development in relation to threshold theory. Journal of Psycholinguistic Research, 21, 301-316.

Rodríguez-Pujadas A, Sanjuán A, Ventura-Campos N, Román P, Martin C, Barceló F, et al. (2013). Bilinguals use language-control brain areas more than monolinguals to perform non-linguistic switching tasks. PLoS ONE, 8 (9). 
Sari, M. (2001). İki dilli cocuklarin cozumleme yontemiyle okuma- yazma ogrenirken karsilastiklari guclukler (yayimlanmamis yuksek lisans tezi). Cukurova Universitesi Egitim Bilimleri Enstitusu. Adana.

Schachter, J.; Mrianne, C, M. (1977). Some reservations concerning error analysis. TESOL Quarterly, 2 (4), 441-451.

Sebba, M. (2012). Multilingualism in written discourse: an approach to the analysis of multilingual texts. International Journal of Bilingualism, 17 (1), 97-118.

Shousha, A.,Farrag, N. M., Althaqafi, A. S. (2020). Analytical assessment of the common writing errors among saudi foundation year students: a comparative study. English Language Teaching, 13 (8), 46-62.

Sijonu, U. (2018). The study of interlingual and intralingual errors of student's descriptive writing at one Private University in Sintang. Journal of English Educational Study, 1 (1), 18-23.

Sonmez, H. (2018). Fransa'da Turkce egitiminin ihtiyaclari uzerine bir durum incelemesi. Turkish Studies Educational Sciences, 13 (27), 1285-1303.

Wang, W.; Wen, Q. (2002). L1 use in the 12 composing process: an exploratory study of 16 Chinese efl writers. Journal of Second Language Writing, 11, 225-246.

Watcharapunyawong, S.; Usaha, S. (2012). Thai EFL students' writing errors in different text types: the interference of the first language. English Language Teaching, 6 (1), 67-78.

Weinstein, C. E.; Hume, L. M. (1998). Study strategies for lifelong learning. Washington D.C: American Psychology Association.

White, R. V.; Arndt, V. (1991). Process writing. Harlow: London

Yagmur, K. (2006). Bati Avrupa'da Turkce ogretiminin sorunlari ve cozum onerileri [ Problems and solutions to teaching Turkish in Western Europe]. Journal of Languge, $134,31-48$.

Yardim, M. (2017). Goc ve entegrasyon politikalari isiginda Fransa'da toplumsal kabulu [Social acceptance in France in the light of immigration and integration policies]. The Journal of Migration Studies, 3 (2), 100-136.

Yavuz, S. (2013). Goc, entegrasyon ve din: Avrupa'da yasayan Turkler baglaminda bir degerlendirme [Migration, integration and religion: an evaluation in the context of Turks living in Europe]. International Journal of Social Research, 6(26), 610-623.

Yildirim, A.; Simsek, H. (2008). Nitel arastirma yontemleri [Qualitative research methods]. Ankara: Seckin Publishing.

Yildiz, C. (2012). Yurt disinda yasayan Turk cocuklarina Turkce ogretimi (Almanya ornegi) [Teaching Turkish to Turkish children living abroad (Germany example)]. Ankara: Republic of Turkey Ministry of Culture and Tourism Presidency for Turks Abroad and Related Communities.

Yilmaz, H. M., Demir, N., (2020). Error analysis: approaches to written texts of Turks living in the Sydney. International Education Studies, 13 (2), 104-114.

Zafar, A. (2016). Error analysis: a tool to improve English skills of undergraduate students. Procedia - Social and Behavioral Sciences, 217 (5), 697-705.

Zoubi, S. M. (2018). The significance of error analysis in written production: a case study of Ajloun National University students. International Journal of English Language and Literature Studies, 7 (4), 150-159. 